\title{
Training in pediatric hepatology across Europe: a survey of the National Societies Network (2016-2019) of the European Society for Paediatric Gastroenterology, Hepatology and Nutrition
}

\author{
Alexandra Papadopoulou a , Carmen Ribes-Koninckx ${ }^{\mathrm{b}}$, Maria Noni ${ }^{\mathrm{a}}$, Eleni Koutria, \\ Maria-Vasiliki Karagiannia , Sue Protheroec, Alfredo Guarino ${ }^{d,}$ Emmanuel Mase, Michael Wilschanskif, \\ Enriqueta Roman', Johanna Escheri, Raoul I. Furlano', Carsten Posovszky', Ilse Hoffman', \\ Gabor Veres $^{+m}$, Jiri Bronsky ${ }^{n}$, Almuthe Christine Hauer ${ }^{\circ}$, Duska Tjesic-Drinkovic ${ }^{p}$, Maria Fotoulaki ${ }^{q}$, \\ Rok Orel', Vaidotas Urbonass, Aydan Kansu', Miglena Georgieva ${ }^{\mathrm{u}}$, Alastair Baker ${ }^{\mathrm{vA}}$ and Deirdre Kelly ${ }^{\mathrm{ct}}$ \\ University of Athens, Agia Sofia Children's Hospital, Athens, Greece; La Fe University Hospital, Valencia, Spain; Birmingham \\ Women's \& Children's Hospital, NHS Foundation Trust, Birmingham, United Kingdom; University of Naples Federico II, \\ Naples, Italy; Children's Hospital, Toulouse University Hospital, Toulouse, France; Hadassah University Hospitals, Jerusalem, \\ Israel; University Hospital Puerta de Hierro-Majadahonda, Madrid, Spain; Erasmus MC-Sophia Children's Hospital, \\ Rotterdam, Netherlands; University Children's Hospital, Basel, Switzerland; University Medical Center Ulm, Ulm, Germany; \\ Leuven University Hospital, Leuven, Belgium; University of Debrecen, Debrecen, Hungary; University Hospital Motol, \\ Prague, Czech Republic; Medical University of Graz, Graz, Austria; University Hospital Center Zagreb, Croatia; Aristotle \\ University of Thessaloniki, Thessaloniki, Greece; Ljubljana University Children's Hospital, Ljubljana, Slovenia; Vilnius \\ University Clinic of Children's Diseases, Vilnius, Lithuania; Ankara University School of Medicine, Ankara, Turkey; Saint \\ Marina University hospital, Varna, Bulgaria; King’s College Hospital, London, United Kingdom
}

Abstract

\begin{abstract}
Background The widely recognized burden of liver diseases makes training in pediatric hepatology $(\mathrm{PH})$ imperative. The aim of this survey, which was part of a global survey on training in pediatric gastroenterology, hepatology and nutrition (PGHN) across Europe, was to assess the $\mathrm{PH}$ and liver transplantation (LT) infrastructure, staff and training programs in PGHN training centers.

Method Standardized questionnaires were collected from training centers via the presidents/ representatives of the National Societies Network of the European Society for Paediatric Gastroenterology, Hepatology and Nutrition (ESPGHAN) from June 2016 to December 2019.

Results A total of 100 PGHN training centers participated in the survey (14/100 were national referral centers in PH and/or LT). Dedicated PH clinics were available in 75\%, but LT clinics in only $11 \%$. Dedicated beds for PGHN inpatients were available in 47/95 (49\%) centers. Full-time or parttime specialists for PH care were available in 31/45 (69\%) and 11/36 (31\%) centers, respectively. Liver biopsies (LB) were performed in $93 \%$ of centers by: a PGHN specialist (35\%); an interventional radiologist (26\%); a pediatric surgeon (4\%); or a combination of them (35\%). Dividing the annual number of LBs in the centers performing LBs by the number of trainees gave a median (range) of 10 (1-125) per trainee. Transient elastography was available in 60/92 (65\%) of centers.
\end{abstract}

Conclusions The survey highlighted the differences and shortcomings in $\mathrm{PH}$ training across Europe. ESPGHAN should take initiatives together with National Societies to ensure the acquisition of PH knowledge and skills according to the ESPGHAN curriculum.

Keywords Hepatology, children, training, pediatric gastroenterology, nutrition

Ann Gastroenterol 2022; 35 (1): 1-7

Correspondence to: Alexandra Papadopoulou, Division of Gastroenterology and Hepatology, First Department of Pediatrics, University of Athens, Agia Sofia Children's Hospital, Thivon and Papadiamantopoulou, 11527, Athens, Greece, e-mail: office.alexandra. papadopoulou@gmail.com

Received 11 November 2021; accepted 22 December 2021; published online 14 February 2022

DOI: https://doi.org/10.20524/aog.2022.0698

\section{Introduction}

Hepatobiliary diseases have a significant impact on pediatric patients. Therefore, trainees in pediatric gastroenterology, hepatology and nutrition (PGHN) should be familiar with their pathophysiological mechanisms and be fully engaged in their diagnosis and management $[1,2]$ so that future pediatric gastroenterologists become 
independent, qualified and competent specialists in these diseases [3-5].

Trainees should be exposed to a sufficient number of patients and a sufficient number of procedures and be able to develop and implement a plan for the diagnosis, management and treatment of patients with such diseases using a multidisciplinary approach [3-5]. The progressive maturation of pediatric hepatology $(\mathrm{PH})$ has led to the determination of a hepatology-focused curriculum and educational content for PGHN training programs, as well as training requirements for those who wish to pursue further training in this specific area. The aim of our survey was to assess the $\mathrm{PH}$-related infrastructure, staff and patient volumes of the various PGHN training centers across Europe.

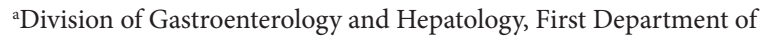
Pediatrics, University of Athens, Agia Sofia Children's Hospital, Athens, Greece (Alexandra Papadopoulou, Maria Noni, Eleni Koutri, Maria-

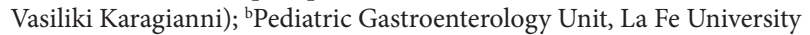
Hospital, Valencia, Spain (Carmen Ribes-Koninckx); 'Birmingham Women's \& Children's Hospital, NHS Foundation Trust, Birmingham, United Kingdom (Sue Protheroe, Deirdre Kelly); ${ }^{\mathrm{d} D e p a r t m e n t ~ o f ~}$ Translational Medical Science, Section of Pediatrics, University of Naples Federico II, Naples, Italy (Alfredo Guarino); ${ }^{\text {eUnit of }}$ Gastroenterology, Hepatology, Nutrition, Diabetes, and Inborn Errors of Metabolism, Children's Hospital, Toulouse University Hospital,

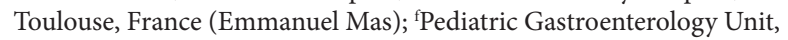
Department of Pediatrics, Hadassah University Hospitals, Jerusalem, Israel (Michael Wilschanski); ${ }^{h}$ Pediatric Gastroenterology Unit, University Hospital Puerta de Hierro-Majadahonda, Madrid, Spain (Enriqueta Roman); 'Department of Pediatric Gastroenterology, Erasmus MC-Sophia Children's Hospital, Rotterdam, Netherlands (Johanna Escher); jDivision of Pediatric Gastroenterology and Nutrition, University Children's Hospital, Basel, Switzerland (Raoul I. Furlano); 'Department of Pediatrics and Adolescent Medicine, University Medical Center Ulm, Ulm, Germany (Carsten Posovszky); ${ }^{1}$ Department of Pediatric Gastroenterology, Leuven University Hospital, Leuven, Belgium (Ilse Hoffman); mediatric Institute-Clinic, University of Debrecen, Debrecen, Hungary (Gabor Veres); ${ }^{\mathrm{n} D e p a r t m e n t}$ of Pediatrics, University Hospital Motol, Prague, Czech Republic (Jiri Bronsky); 'Department of Pediatrics, Medical University of Graz, Graz, Austria (Almuthe Christine Hauer); pUniversity Hospital Center Zagreb - Division for Pediatric Gastroenterology, Hepatology and Nutrition \& University of Zagreb School of Medicine, Zagreb, Croatia (Duska Tjesic-Drinkovic); ${ }^{\mathrm{q}} 4^{\text {th }}$ Department of Pediatrics, Aristotle University of Thessaloniki, Thessaloniki, Greece (Maria Fotoulaki); rDepartment of Gastroenterology, Hepatology and Nutrition, Ljubljana University

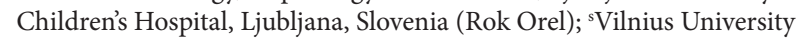
Clinic of Children's Diseases, Vilnius, Lithuania (Vaidotas Urbonas); 'Division of Pediatric Gastroenterology, Department of Pediatrics, Ankara University School of Medicine, Ankara, Turkey (Aydan Kansu); u2 ${ }^{\text {nd }}$ Department of Pediatrics, Saint Marina University hospital, Varna, Bulgaria (Miglena Georgieva); 'Pediatric Liver Center, King's College Hospital, London, United Kingdom (Alastair Baker)

\# Both DK and $\mathrm{AB}$ share the last authorship

Conflict of Interest: None

Disclaimer: This paper was developed by the ESPGHAN National Societies Network. It does not necessarily represent ESPGHAN policy and is not formally endorsed by the ESPGHAN Council.

Funding: This project was supported by the European Society for Paediatric Gastroenterology, Hepatology and Nutrition

\section{Materials and methods}

This study constitutes a subgroup analysis of a major project to examine the infrastructure, staffing, patient and procedure volume and organization of PGHN training in PGHN training centers across Europe. Questions related to $\mathrm{PH}$ and liver transplantation (LT) were included in the standardized questionnaires (Supplementary Appendix 1) created by the members (AP, AB and CRC) of the Executive Committee of the National Societies Group 2015-2017 of the European Society for Paediatric Gastroenterology, Hepatology and Nutrition (ESPGHAN) and sent to the presidents/representatives of the ESPGHAN National Societies, who distributed them to the heads of PGHN training centers in their countries and collected the responses. In countries where no official National Society representative participated in the survey (Italy, Portugal and Switzerland), a volunteer among ESPGHAN members from that country was asked to distribute and collect the questionnaires (Italy and Switzerland), or individual centers provided their data after direct communication with the study coordinators (Portugal). The project was approved by the ESPGHAN Council in 2016 and supported by ESPGHAN. It was implemented from 1 June 2016 to 31 December 2019. The manuscript was sent for review and constructive comments to the former ESPGHAN President, former Chair of the ESPGHAN Hepatology Committee and Public Affairs Committee, Professor of Pediatric Hepatology, DK.

\section{Statistical analysis}

Appropriate statistical analysis was performed with the use of IBM SPSS software. Descriptive statistics was performed to characterize study groups. Continuous data were tested for normality using the Kolmogorov-Smirnoff test and graphical methods (histogram, Q-Q plot). For normally distributed variables, the Student's $t$-test was used to assess differences between groups, and the Mann-Whitney $U$ test for skewed variables. For categorical data, the $\chi^{2}$ test was used, or the Fisher exact test where data were not suitable for $\chi^{2}$ testing. ANOVA or the Kruskal-Wallis test was used to test for differences in continuous variables among more than 2 groups, depending on the variables' distribution. Correlations among continuous variables were analyzed using Spearman's or Pearson's test, depending on the variables' distribution. Factors found to be statistically significant in univariate analyses were included in the multivariate analyses to identify independent associations, if any. All statistical analyses were performed with the statistical package SPSS Statistics 21 (SPSS, Inc., Chicago, IL, USA). Statistical significance at $\mathrm{P}<0.05$ will be assumed.

\section{Results}

A total of 100 training centers from 17 European countries, Turkey and Israel (Supplementary Appendix 2), participated in the survey. Seventy of these were national referral centers-43 
in PGHN (Group 1), 14 in PH and/or LT (Group 2), and 13 in pediatric gastroenterology (PG; Group 3)-and 30 were regional referral centers. Thirty training centers were in the capital cities of the 19 countries: 29 were national referral centers (20 in PGHN, 4 in PH and/or LT and 5 in PG), while one was a regional referral center.

The age limit for patient care by most of these centers is 18 years. However, the center in Innsbruck cares for children up to the age of 16 years, while 2 centers (in Rome and Zagreb) care for patients up to the age of 21 years. Dedicated clinics for PH and/or LT were present in 68/91 (75\%) centers: $49 / 64(77 \%)$ of the national referral centers that answered the relevant question and 19/27 (70\%) of the regional centers. Among the groups of national referral centers, dedicated clinics for PH and/or LT were present in 25/37 (68\%) centers in Group 1, in 14/14 (100\%) in Group 2 and in 10/13 (77\%) in Group 3. However, dedicated clinics for LT were available in only $9 / 84(11 \%)$ centers, 8 of which were national referral centers: $0 / 31(0 \%)$ in Group 1, 7/12 (58.3\%) in Group 2 and $1 / 12(8 \%)$ in Group 3 (jointly with a national PH/LT referral center). Furthermore, dedicated clinics for $\mathrm{PH}$ and/or LT were present in 20/28 (71\%) of the training centers established in European capitals that answered the relevant question.

Dedicated beds for pediatric gastroenterology and hepatology inpatients were available in 37/69 (54\%) of the national referral centers that answered the relevant question in the total cohort, and in 10/14 (71\%) of the national referral centers for PH. Fulltime specialists for PH care were available in 31/45 (69\%) of centers and part-time specialists in 11/36 (31\%) of training centers (Table 1). Liver biopsies (LB) were performed in 85 training centers (Table 2). The performers of LBs in different training centers were the following: PGHN specialists in 35\% of training centers, interventional radiologists in $26 \%$, surgeons in $4 \%$, and a combination of them in $35 \%$ (Table 1). Transient elastography was available in 60/92 (65\%) training centers (Table 1).

The annual number of procedures in the training centers of the total cohort is shown in Table 1. Annual numbers of LBs $>100$ were reported by 6 national referral centers for PH and LT (King's College Hospital, London, UK; Birmingham Children's Hospital, UK; Saint-Luc University Hospital, Catholic University de Louvain, Brussels, Belgium; Papa Giovanni XXIII Hospital, Bergamo, Italy; Woman Mother Child Hospital, Lyon, France; Schneider Children's Medical Center of Israel, Petah Tiqva, Israel). Ten LBs or fewer per year were reported by $61 \%$ of regional centers compared to $30 \%$ of national referral centers $(\mathrm{P}=0.022$; Table 2). A multinomial logistic regression analysis showed that national $\mathrm{PH}$ referral centers were more likely to perform large numbers of LBs (51-100 or $>100$ liver biopsies per year) than any other centers $(\mathrm{P}<0.001$; Table 2$)$. No significant differences in procedure volume were found between training centers located in European capitals and other cities $(\mathrm{P}=0.377$; Table 2). The annual procedural volume in the training centers of the total cohort, according to the number of outpatients, is shown in Table 3. Thirty-two of 85 (38\%) training centers reported a low number $(\leq 10)$ of LBs per year (Table 3$)$. Low $(\leq 10)$ annual numbers of LBs were reported by $60 \%$ of centers with less than 1500 outpatients per year, but also by $19 \%$ of those centers with the highest ( $>5000$ ) annual numbers of outpatients (Table 3).

Dividing the total number of LBs performed at the training center per year by the number of trainees, the median (interquartile range, range) annual number of LB per trainee in the cohort of centers performing LBs, is 10 (5-28, 1-125). Significant differences were found between national referral centers and regional centers $(\mathrm{P}=0.06)$ and between different categories of training centers $(\mathrm{P}=0.005)$, with trainees in $\mathrm{PH}$ national referral centers having the greatest exposure to LBs.

Table 1 Availability of specialists for PH care, availability of transient elastography and liver biopsy operators in PGHN training centers

\begin{tabular}{|c|c|c|c|c|c|c|}
\hline Specialists & $\begin{array}{c}\text { National } \\
\text { referral centers } \\
\text { in PGHN } \\
(\mathrm{n}=43)\end{array}$ & $\begin{array}{c}\text { National } \\
\text { referral } \\
\text { centers in } \mathrm{PH} \\
(\mathrm{n}=14)\end{array}$ & $\begin{array}{l}\text { National } \\
\text { referral } \\
\text { centers in } \\
\text { PG }(n=13)\end{array}$ & $\begin{array}{l}\text { Regional } \\
\text { centers } \\
(n=30)\end{array}$ & $\begin{array}{l}\text { Centers in } \\
\text { European } \\
\text { capitals } \\
(\mathrm{n}=30)\end{array}$ & $\begin{array}{c}\text { Centers in } \\
\text { other cities } \\
(\mathrm{n}=70)\end{array}$ \\
\hline \multicolumn{7}{|l|}{$\begin{array}{l}\text { Availability of full-time/part-time } \\
\text { specialist for PH care }\end{array}$} \\
\hline Full-time & $13 / 21(62 \%)$ & $9 / 9(100 \%)$ & $5 / 8(63 \%)$ & $4 / 7(57 \%)$ & $11 / 15(73 \%)$ & $20 / 30(67 \%)$ \\
\hline Part-time & $5 / 16(31 \%)$ & $3 / 6(50 \%)$ & $1 / 7(14 \%)$ & $2 / 7(29 \%)$ & $4 / 9(44 \%)$ & $7 / 27(26 \%)$ \\
\hline \multicolumn{7}{|l|}{ Liver biopsy operator } \\
\hline PGHN specialist only & $17 / 40(43 \%)$ & $4 / 12(33 \%)$ & $3 / 11(27 \%)$ & $8 / 29(28 \%)$ & $12 / 28(43 \%)$ & $20 / 64(31 \%)$ \\
\hline Interventional radiologist only & $9 / 40(22 \%)$ & $0 / 12(0 \%)$ & $3 / 11(27 \%)$ & $12 / 29(41 \%)$ & $7 / 28(25 \%)$ & $17 / 64(27 \%)$ \\
\hline Pediatric surgeon only & $3 / 40(8 \%)$ & $0 / 12(0 \%)$ & $0 / 11(0 \%)$ & $1 / 29(3 \%)$ & $2 / 28(7 \%)$ & $2 / 64(3 \%)$ \\
\hline $\begin{array}{l}\text { PGHN specialist and } \\
\text { interventional radiologist }\end{array}$ & $6 / 40(15 \%)$ & $5 / 12(42 \%)$ & $2 / 11(18 \%)$ & $6 / 29(21 \%)$ & $4 / 28(14 \%)$ & $15 / 64(23 \%)$ \\
\hline $\begin{array}{l}\text { PGHN specialist and } \\
\text { pediatric surgeon }\end{array}$ & $3 / 40(8 \%)$ & $3 / 12(25 \%)$ & $3 / 11(27 \%)$ & $2 / 29(7 \%)$ & $1 / 28(4 \%)$ & $10 / 64(16 \%)$ \\
\hline $\begin{array}{l}\text { Interventional radiologist and } \\
\text { pediatric surgeon }\end{array}$ & $2 / 40(5 \%)$ & $0 / 12(0 \%)$ & $0 / 11(0 \%)$ & $0 / 29(0 \%)$ & $2 / 28(7 \%)$ & $0 / 64(0 \%)$ \\
\hline \multicolumn{7}{|l|}{$\begin{array}{l}\text { Availability of transient } \\
\text { elastography }\end{array}$} \\
\hline Transient elastography & $24 / 39(62 \%)$ & $9 / 13(69 \%)$ & $8 / 11(73 \%)$ & $19 / 29(66 \%)$ & $15 / 25(60 \%)$ & $45 / 67(67 \%)$ \\
\hline
\end{tabular}

PGHN, pediatric gastroenterology, hepatology and nutrition; PG, pediatric gastroenterology; $P H$, pediatric hepatology; The numerators indicate the number of centers that answered the corresponding question and the dominators indicate the total number of centers 
Table 2 Annual numbers of liver biopsies performed at the PGHN training centers across Europe

\begin{tabular}{lcccccc}
\hline $\begin{array}{l}\text { No of liver } \\
\text { biopsies }\end{array}$ & $\begin{array}{c}\text { National referral } \\
\text { centers in PGHN } \\
(\mathrm{n}=38 / 43)\end{array}$ & $\begin{array}{c}\text { National referral } \\
\text { centers in PH } \\
(\mathrm{n}=13 / 14)\end{array}$ & $\begin{array}{c}\text { National referral } \\
\text { centers in PG } \\
(\mathrm{n}=11 / 13)\end{array}$ & $\begin{array}{c}\text { Regional } \\
\text { centers } \\
(\mathrm{n}=23 / 30)\end{array}$ & $\begin{array}{c}\text { Centers in } \\
\text { European capitals } \\
(\mathrm{n}=24 / 30)\end{array}$ & $\begin{array}{c}\text { Centers in } \\
\text { other cities } \\
(\mathrm{n}=61 / 70)\end{array}$ \\
\hline$\leq 10$ & $12 / 38(32 \%)$ & $0 / 13(7.1 \%)$ & $6 / 11(55 \%)$ & $14 / 23(61 \%)$ & $8 / 24(33 \%)$ & $24 / 61(39 \%)$ \\
$11-50$ & $20 / 38(53 \%)$ & $5 / 13(36 \%)$ & $5 / 11(46 \%)$ & $9 / 23(39 \%)$ & $10 / 24(42 \%)$ & $29 / 61(48 \%)$ \\
$51-100$ & $3 / 38(8 \%)$ & $5 / 13(36 \%)$ & $0 / 11(0 \%)$ & $0 / 23(0 \%)$ & $3 / 24(13 \%)$ & $5 / 61(8 \%)$ \\
$>100$ & $3 / 38(8 \%)$ & $3 / 13(21 \%)$ & $0 / 11(0 \%)$ & $0 / 23(0 \%)$ & $3 / 24(13 \%)$ & $3 / 61(5 \%)$ \\
\hline
\end{tabular}

The numerators indicate the number of centers that answered the corresponding question and the dominators indicate the total number of centers PGHN, pediatric gastroenterology, hepatology and nutrition; $P G$, pediatric gastroenterology; $P H$, pediatric hepatology

Table 3 Annual procedural volume of liver biopsies performed by training centers according to the annual numbers of outpatients

\begin{tabular}{lcccc}
\hline Annual No of outpatients & $\leq 10$ & $11-50$ & $51-100$ & $>100$ \\
\hline$\leq 500\left(\mathrm{n}=3^{*}\right)$ & $3 / 3(100 \%)$ & $0 / 3(0 \%)$ & $0 / 3(0 \%)$ & $0 / 3(0 \%)$ \\
$501-1500\left(\mathrm{n}=12^{*}\right)$ & $6 / 12(50 \%)$ & $5 / 12(42 \%)$ & $1 / 12(8 \%)$ & $0 / 12(0 \%)$ \\
$1501-3000\left(\mathrm{n}=28^{*}\right)$ & $12 / 28(43 \%)$ & $11 / 28(39 \%)$ & $4 / 28(14 \%)$ & $1 / 28(4 \%)$ \\
$3001-5000\left(\mathrm{n}=24^{*}\right)$ & $8 / 24(33 \%)$ & $13 / 24(54 \%)$ & $0 / 24(0 \%)$ & $3 / 24(13 \%)$ \\
$>5000\left(\mathrm{n}=16^{*}\right)$ & $3 / 16(19 \%)$ & $8 / 16(50 \%)$ & $3 / 16(19 \%)$ & $2 / 16(13 \%)$ \\
\hline
\end{tabular}

${ }^{{ } T h e}$ numbers indicate the number of centers that answered the question about the center's outpatient volume per year and the annual number of liver biopsies performed

No significant differences were found between centers located in capital cities compared to other cities ( $\mathrm{P}=0.659$; Table 4$)$.

We were interested in finding out if there are differences between countries in the frequency with which LBs are performed in the population aged 0-19 years. The number of LBs per 100,000 population aged 0-19 years performed annually by all training centers in countries where training centers are fully represented in the survey is shown in Fig. 1. The population aged 0-19 years is from the international database of the United States Census Bureau [6]. Although countries with a larger number of children aged 0-19 years reported a higher number of LBs $\left(r_{s}=0.714 ; P=0.047\right)$, the number of LBs per 100,000 population aged $0-19$ years did not correlate with the number of children per country $\left(r_{s}=-0.071 ; P=0.867\right)$. We were also interested in knowing the procedural volumes of the major centers in each country among those participating in the survey, to identify potential training centers in each country and at a European level. The annual number of LBs performed by the PGHN centers with the largest procedural volumes among the participating centers in each country is shown in Fig. 2. Twelve of the 18 centers were pediatric liver transplant centers. The total number of PGHN specialists in the top 6 centers (i.e., those with the highest number of LBs) was 52 ( 37 fulltime), while it was 22 (13 fulltime) in the 6 centers with the lowest number of LBs and 38 (29 fulltime) in the 6 centers with a medium number of LBs. The centers with the highest numbers of procedures had a larger outpatient volume, as $5 / 6(83 \%)$ of the top 6 centers reported $>3000$ outpatients per year $(3 / 6,>5000)$, which was not the case for the centers with a medium or the lowest number of LBs, as only $2 / 6(33 \%)$ of the centers with a medium number and $2 / 6(33 \%)$ of centers with the lowest number of LBs have reported $>3000$ outpatients per year.

\section{Discussion}

The survey shows that the infrastructure, staff, training program, patients and procedural volumes related to $\mathrm{PH}$ vary widely across PGHN training centers in Europe. Dedicated clinics for $\mathrm{PH}$ were present in $3 / 4$ of the training centers, while dedicated clinics for LT were present in only one tenth. Fulltime specialists to care for $\mathrm{PH}$ patients were reported by $2 / 3$ of the training centers and part-time specialists by almost $1 / 3$. Dedicated beds for pediatric gastroenterology and hepatology inpatients were reported by half of the training centers. The number of LBs varied considerably among the different training centers, as $38 \%$ of them performed $10 \mathrm{LBs}$ or fewer per year, while 6 national reference centers for $\mathrm{PH}$ and LT performed more than 100 LBs per year. Trainees on fellowship at the latter centers were exposed to double to quadruple the number of LBs. The latter training centers also had the largest outpatient volumes, with $2 / 5$ of them exceeding 5000 outpatients per year. In about $1 / 3$ of the training centers LBs were performed only by PGHN specialists, in $1 / 4$ only by interventional radiologists, while in about $1 / 3$ LBs involved a combination of different specialists (PGHN, interventional radiologists or pediatric surgeons).

Williams et al highlighted the increasing burden of liver diseases and specific problems in hepatology training in the UK [7]. In 2013, the Hepatology Advanced Training Program was launched to provide clinicians with the opportunity to obtain a subspecialty certificate in hepatology, with only 20 posts available each year [8]. The PGHN training curriculum proposed by both ESPGHAN [3,4] and the North American Society for Pediatric Gastroenterology, Hepatology and Nutrition (NASPGHAN) [5] provides a broad knowledge of hepatobiliary diseases. In addition, NASPGHAN envisages 
Table 4 Median (IQR; range) number of trainees in training centers performing liver biopsies and median (IQR; range) annual number of liver biopsies per trainee

\begin{tabular}{|c|c|c|c|}
\hline Center & $\begin{array}{c}\text { No of trainees } \\
\text { (median IQR; range) }\end{array}$ & $\begin{array}{l}\text { No of LBs per trainee } \\
\text { (median IQR; range) }\end{array}$ & P-value \\
\hline National referral center $(n=70)$ & $2(1-5 ; 0-10)$ & $13^{*}(6-33 ; 1-125)$ & \\
\hline Regional center $(\mathrm{n}=30)$ & $2(1-3 ; 0-10)$ & $10^{* *}(5-13 ; 2-20)$ & ${ }^{*}$ vs. ${ }^{* *} 0.06$ \\
\hline National referral center in PGHN $(n=43)$ & $2(1-3 ; 1-6)$ & $10^{\wedge}(5-30 ; 1-83)$ & \\
\hline National referral center in $\mathrm{PH}(\mathrm{n}=14)$ & $2(1-2 ; 0-5)$ & $38^{\wedge \wedge}(28-70 ; 3-125)$ & \\
\hline National referral center in PG $(n=13)$ & $2(1-5 ; 0-10)$ & $8^{\wedge \wedge \wedge \wedge}(5-15 ; 3-20)$ & $\wedge$ vs. $\wedge \wedge$ vs. $\wedge \wedge \wedge 0.005$ \\
\hline Centers in capitals $(n=30)$ & $2(1-5 ; 1-10)$ & $13 \#(6-31 ; 1-83)$ & \\
\hline Centers in other cities $(n=70)$ & $2(1-2 ; 0-7)$ & $10 \# \#(5-20 ; 2-125)$ & \# vs. \#\# 0.659 \\
\hline
\end{tabular}

IQR, interquartile range; $P G H N$, pediatric gastroenterology, hepatology and nutrition; $P G$, pediatric gastroenterology; PH, pediatric hepatology; LBs, liver biopsies

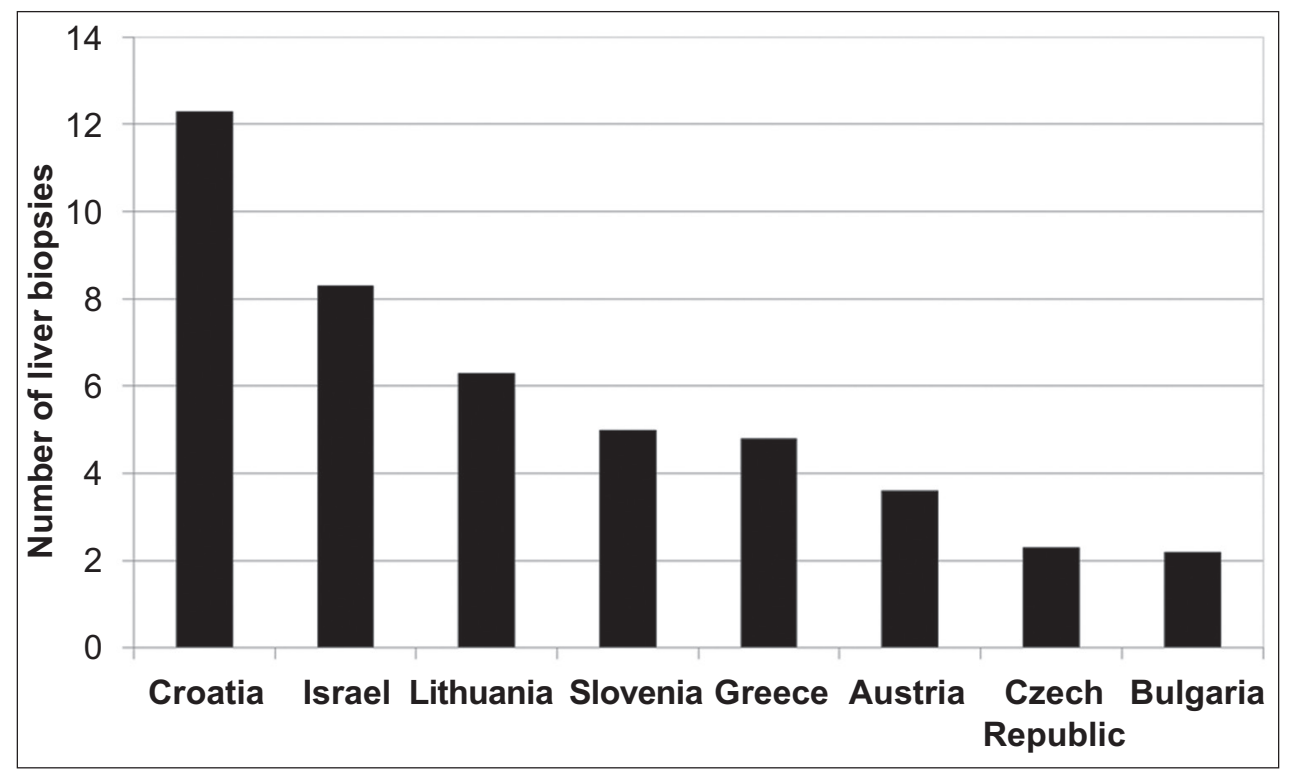

Figure 1 Annual number of liver biopsies per 100,000 population aged 0-19 years [7] in countries with full representation of the pediatric gastroenterology, hepatology and nutrition training centers

a special $\mathrm{PH}$ fellowship program to improve expertise in pediatric $\mathrm{PH}$ and LT [5].

There is reportedly a variety of training opportunities in hepatology in the UK, even for adult specialists [9], and the Lancet Commission proposed the establishment of dedicated liver centers in district general hospitals to improve training in this important area [7]. Early identification of training fellows interested in hepatology can provide future specialists with the necessary knowledge, experience and skills to provide the best possible care to patients with hepatobiliary diseases $[10,11]$.

Our survey showed that the age range of the children cared for by the different centers varied: it ranged from 16 years in Innsbruck to 21 years in Rome and Zagreb PH and LT centers. However, it is common knowledge that patients with chronic diseases need medical care into adulthood. Health care transition should be understood as a targeted, planned transition of adolescents with chronic diseases from a child-centered to an adult-centered healthcare system [12], taking into account that this particular patient age group is at high risk for developmental and psychosocial problems. A successful transition program can limit some of the psychosocial effects of chronic illness by improving self-efficacy and autonomy, as well as treatment adherence [13-15].

Furthermore, differences in the number of procedures per 100,000 population aged $0-19$ years were evident between countries, with Croatia reporting the highest number of LBs, while the Czech Republic and Bulgaria report the lowest, although the reasons for these differences are not known. The ESPGHAN Position Paper on LB [16] describes the clinical indications for performing LBs to diagnose liver disease. However, implementation of the guidelines in clinical practice is not always possible. Strategies are needed to improve the adoption, implementation and sustainability of guidelines. At the same time, the most important criterion by which aspects of medical care should be measured is disease outcome, which was outside the scope of this survey, with improvement in outcomes following a particular intervention being the real benefit. 


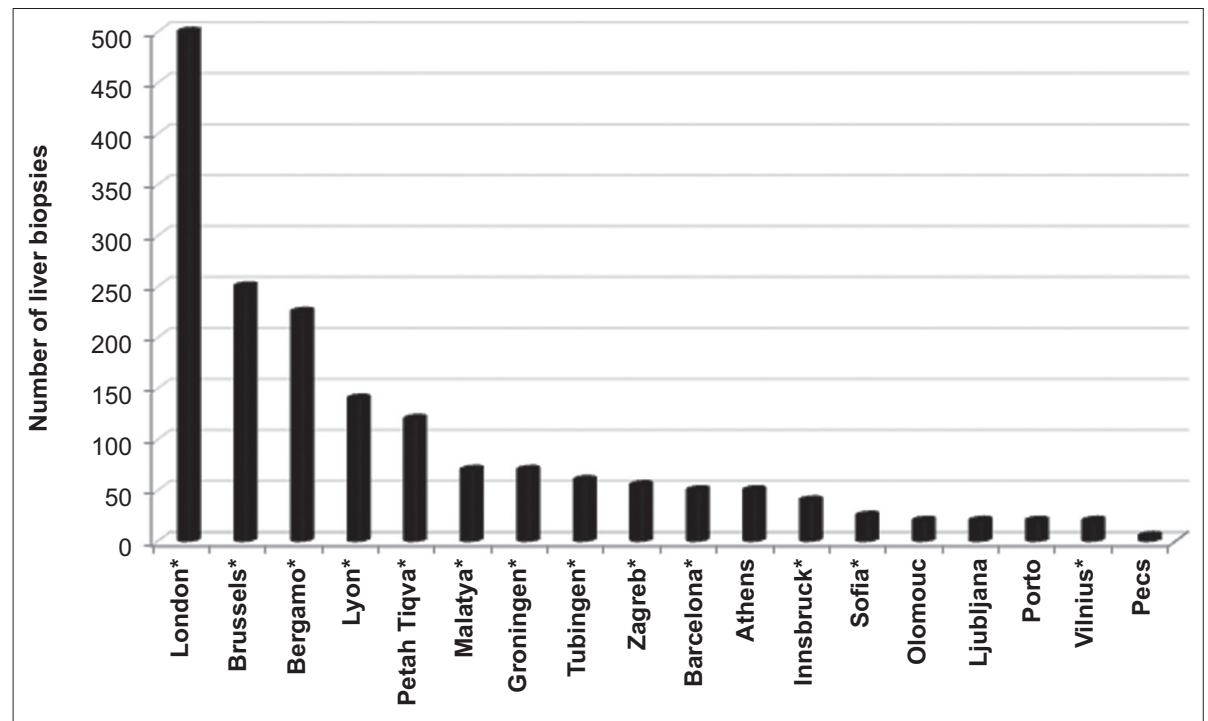

Figure 2 Annual number of liver biopsies performed by the pediatric gastroenterology, hepatology and nutrition center with the largest procedural volume amongst participating centers in each country. The centers shown in the figure are the following: London (King's College Hospital); Brussels (Saint-Luc University Hospital); Bergamo (Papa Giovanni XXIII Hospital); Lyon (Woman Mother Child Hospital); Petah Tiqva (Schneider Children's Medical Center of Israel); Malatya (Inönü University Faculty of Medicine); Groningen (University Medical Center Groningen); Tübingen (University Children's Hospital, Tubingen); Zagreb (University Hospital Center Zagreb); Barcelona (Vall d'Hebron University Hospital); Athens (Agia Sofia Children's hospital); Innsbruck (Innsbruck Medical University); Sofia (Ivan Mitev Specialized Hospital for Active Treatment of Children's Diseases); Olomouc (Olomouc University Hospital), Ljubljana (Ljubljana University Medical Center); Porto (São João University Hospital); Vilnius (Vilnius University Hospital Santaros Klinikos); Pécs (Pécs University Medical School). ${ }^{*}$ ) Centers with pediatric liver transplant programs

Regarding training, there are currently no universally accepted recommendations for the training and experience required to qualify a person to perform LBs. The American Association for the Study of Liver Disease recommended a minimum of 40 LBs under supervision [17], while NASPGHAN recommended a minimum of 20 LBs performed independently, of which half should be in infants and children aged $<3$ years [18]. A similar number of LBs was also recommended by the American Gastroenterology Association in "Training the Gastroenterologist for the Future" [19]. A minimum number of 50 procedures was recommended by the British and Irish Committee on Higher Medical Training [20]. The effect of the experience of the person performing LBs on the adequacy of the obtained liver tissue and on complication rate is poorly defined [21]. An audit carried out by the British Society of Gastroenterology in 1991 reported a slightly higher incidence of complications if the operator had performed $<20$ LBs compared with $>100$ (3.2\% vs. $1.1 \%)$ [22]. Regarding the ability to obtain adequate tissue, one report claimed that physician assistants who observed $10 \mathrm{LBs}$, practiced on inanimate objects, and then performed $30 \mathrm{LBs}$ under supervision were able to obtain adequate tissue in $99.1 \%$ of attempts after a single pass and in 99.8\% after 2 passes, with a mean tissue length of $3.2 \mathrm{~cm}$ [23]. Another report claimed that, in a series of 101 LBs performed independently by a hepatologist with no prior experience in ultrasound diagnostics, after observing 64 LBs performed by a certified ultrasound technician, no differences in complication rate or in adequacy of the obtained liver tissue were found [24]. The authors of the Position Paper on LB of the ESPGHAN Hepatology Committee suggested that a minimum of 20 LBs should be performed under supervision [16]. Based on the above, it is reasonable for low procedure volume training centers to work with larger centers within a clinical network. Clinical networks provide opportunities for multidisciplinary team meetings between doctors, surgeons and other professionals, audits and other quality improvement activities, data management, shared information technology protocols and research [25]. They provide access to specialized care, regardless of where patients live, and ensure that access to specialist advice is available by telephone 24/7. Specialist hepatology services and training in hepatology are provided in the UK by 3 leading specialist centers in Leeds, Birmingham and London [25]. Access to these services is by direct referral from primary or secondary services or by referral from the specialist gastroenterology service. Shared care is provided through network arrangements, including outreach clinics organized in close collaboration with local and specialist pediatric consultants, offering joint consultations and agreed local investigations and treatment.

This study had a number of limitations, such as the crosssectional study design and the variability of the response rate, as there were countries where PGHN training centers were fully represented (Austria, Bulgaria, Czech Republic, Croatia, Greece, Israel, Lithuania and Slovenia), while other countries such as Germany and Turkey had limited representation, as only a few centers participated in the survey. However, the greatest value of this survey is that this first collaborative work of the ESPGHAN National Societies provides the largest set of data on the infrastructure, staffing, number of procedures and training programs in $\mathrm{PH}$ across Europe, identifying discrepancies that can help ESPGHAN, together with the National Societies, to develop actions to fill the identified gaps to achieve excellence in training and medical care across Europe. 
In conclusion, this survey showed clear differences and deficits in terms of $\mathrm{PH}$ infrastructure, staff, patient and procedure volumes, and thus training opportunities, between PGHN training centers across Europe. ESPGHAN, together with the National Societies, should take initiatives for a well-structured training program according to the ESPGHAN curriculum, supporting the rotation of trainees to referral centers with large patient and procedure volumes and their participation in training courses and schools, as well as for developing competence assessment and accreditation measures where these are lacking.

\section{Summary Box}

\section{What is already known:}

- The goal of the training program in pediatric hepatology is to provide excellent clinical and research training, so that pediatric gastroenterologists become independent, qualified and competent specialists in liver diseases

\section{What the new finding is:}

- Major differences exist in the infrastructure, staff, training programs, patients, and procedural volumes, between pediatric gastroenterology, hepatology and nutrition training centers across Europe

\section{References}

1. Balistreri WF. Growth and development of a new subspecialty: pediatric hepatology. Hepatology 2013;58:458-476.

2. Walker WA, Sherman P, Cohen M, Barnard J. State of pediatric gastroenterology, hepatology, and nutrition: 2006 and beyond. Gastroenterology 2007;132:434-436.

3. D'Antiga L, Nicastro E, Papadopoulou A, et al. European Society for Pediatric Gastroenterology, Hepatology, and Nutrition syllabus for subspecialty training: moving towards a European standard. J Pediatr Gastroenterol Nutr 2014;59:417-422.

4. European Society for Paediatric Gastroenterology, Hepatology and Nutrition. ESPGHAN Training Syllabus 2019. Available from: https://www.espghan.org/knowledge-center/education/ ESPGHAN_Training_Syllabus_2019 [Accessed 21 January 2022].

5. Leichtner AM, Gillis LA, Gupta S, et al; North American Society for Pediatric Gastroenterology. NASPGHAN guidelines for training in pediatric gastroenterology. J Pediatr Gastroenterol Nutr 2013;56(Suppl 1):S1-S8.

6. International Database: World Population Estimates and Projections. Available from: https://www.census.gov/data-tools/demo/idb/\#/ map?COUNTRY_YR_ANIM=2021\&menu=mapViz\&COUNTRY_ YEAR $=$ [Accessed 6 February 2022].

7. Williams R, Ashton K, Aspinall R, et al. Implementation of the Lancet Standing Commission on Liver Disease in the UK. Lancet 2015;386:2098-2111.

8. Corrigan M, Alrubaiy L, China L; British Society of Gastroenterology Trainees Section. Hepatology training in the UK. Lancet 2016;387:1055.
9. Neale JR, Basford PJ. General medical training in gastroenterology: Views from specialist trainees on the challenges of dual accreditation. Clin Med (Lond) 2015;15:35-39.

10. British Society of Gastroenterology. BSG/BASL Position Statement on Hepatology Training. Available from: https://www.bsg.org.uk/ clinical-resource/bsg-basl-position-statement-on-hepatologytraining/[Accessed 21 January 2022].

11. Ordway SM, Singla MB, Young PE, Satoskar R, Kwok RM. Factors influencing decisions about a career in hepatology: A survey of gastroenterology fellows. Hepatol Commun 2017;1:347-353.

12. Blum RW, Garell D, Hodgman CH, et al. Transition from childcentered to adult health-care systems for adolescents with chronic conditions. A position paper of the Society for Adolescent Medicine. J Adolesc Health 1993;14:570-576.

13. Rosen DS, Blum RW, Britto M, Sawyer SM, Siegel DM; Society for Adolescent Medicine. Transition to adult health care for adolescents and young adults with chronic conditions: position paper of the Society for Adolescent Medicine. J Adolesc Health 2003;33:309-311.

14. Reed-Knight B, Lewis JD, Blount RL. Association of disease, adolescent, and family factors with medication adherence in pediatric inflammatory bowel disease. $J$ Pediatr Psychol 2011;36:308-317.

15. Dabadie A, Troadec F, Heresbach D, Siproudhis L, Pagenault M, Bretagne JF. Transition of patients with inflammatory bowel disease from pediatric to adult care. Gastroenterol Clin Biol 2008;32:451-459.

16. Dezsőfi A, Baumann U, Dhawan A, et al; ESPGHAN Hepatology Committee. Liver biopsy in children: position paper of the ESPGHAN Hepatology Committee. J Pediatr Gastroenterol Nutr 2015;60:408-420.

17. Rockey DC, Caldwell SH, Goodman ZD, Nelson RC, Smith AD; American Association for the Study of Liver Diseases. Liver biopsy. Hepatology 2009;49:1017-1044.

18. Rudolph CD, Winter HS. NASPGN guidelines for training in pediatric gastroenterology. NASPGN Executive Council, NASPGN Training and Education Committee. J Pediatr Gastroenterol Nutr 1999;29(Suppl 1):S1-S26.

19. American Association for the Study of Liver Diseases; American College of Gastroenterology; American Gastroenterological Association; American Society for Gastrointestinal Endoscopy. Training the gastroenterologist of the future: the Gastroenterology Core Curriculum. Gastroenterology 2003;124:1055-1104.

20. Shah S, Mayberry JF, Wicks AC, Rees Y, Playford RJ. Liver biopsy under ultrasound control: implications for training in the Calman era. Gut 1999;45:628-629.

21. Westheim BH, Aagenæs I, Østensen AB, Sanengen T, Almaas R. Effect of operator experience and frequency of procedure performance on complication rate after ultrasound-guided percutaneous liver biopsies. J Pediatr Gastroenterol Nutr 2013;57:638-643.

22. Gilmore IT, Burroughs A, Murray-Lyon IM, Williams R, Jenkins D, Hopkins A. Indications, methods, and outcomes of percutaneous liver biopsy in England and Wales: an audit by the British Society of Gastroenterology and the Royal College of Physicians of London. Gut 1995;36:437-441.

23. Gunneson TJ, Menon KV, Wiesner RH, et al. Ultrasound-assisted percutaneous liver biopsy performed by a physician assistant. Am J Gastroenterol 2002;97:1472-1475.

24. Riley TR $3^{\text {rd }}$. How often does ultrasound marking change the liver biopsy site? Am J Gastroenterol 1999;94:3320-3322.

25. Royal College of Paediatrics and Child Health and British Society of Paediatric Gastroenterology, Hepatology and Nutrition. Quality standards for paediatric gastroenterology, hepatology \& nutrition. 2017. Available from: https://www.rcpch.ac.uk/sites/ default/files/2018-03/standards_for_paediatric_gastroenterology_ hepatology_and_nutrition.pdf [Accessed 21 January 2022]. 


\section{Supplementary material}

\section{Supplementary Appendix 1}

\section{Questionnaire}

EUROPEAN SURVEY ON PEDIATRIC
GASTROENTEROLOGY, HEPATOLOGY AND NUTRITION
TRAINING CENTERS
Name of the Training Center
City:...... Country:.......
Contact Person: Name ..................
Position $\ldots \ldots \ldots \ldots \ldots \ldots$
e-mail:

\section{Information on Training Programs}

Does the Center provide:

- full training in pedGHN $\mathrm{Y} \square \mathrm{N} \square$ number of training places

- training only in gastroenterology $\mathrm{Y} \square \mathrm{N} \square$ number of training places ()

- training only in hepatology $\mathrm{Y} \square \mathrm{N} \square$ number of training places ()

- training in nutritional care $\mathrm{Y} \square \mathrm{N} \square$ number of training places ()

- training in research techniques $\mathrm{Y} \square \mathrm{N} \square$ number of training places ()

- Is research mandatory in training? $\mathrm{Y} \square \mathrm{N} \square$ but strongly recommended

- training in pancreatic diseases $\mathrm{Y} \square \mathrm{N} \square$ number of training places

- training in metabolic diseases $\mathrm{Y} \square \mathrm{N} \square$ number of training places

- training in transplantation $\mathrm{Y} \square \mathrm{N} \square$ number of training places

- training in nutritional failure $\mathrm{Y} \square \mathrm{N} \square$ number of training places

- Maximum number of trainees in post at any given time:

Does your department have a training lead? $\mathrm{Y} \square \mathrm{N} \square$

Does your department have training links/relationships with other departments? $\mathrm{Y} \square \mathrm{N} \square$

Does your department have a training curriculum? $\mathrm{Y} \square \mathrm{N} \square$

Minimum duration of training:....

Which formal body certifies your trainees as competent?...... Please summarise how trainees are assessed

Global assessment + technical skills + personal project (presentation and publication)

\section{GENERAL DATA}

Is it a National Referral Center for PGHN

For all GI specialities $\mathrm{Y} \square \mathrm{N} \square$

Only for specific subspecialties $\mathrm{Y} \square \mathrm{N} \square$, which one(s)

Is it a Regional Referral Center for PGHN Y $\square \mathrm{N} \square$

Cut off age range for Chronic Gastro Hepatology diseases in the Center

Population served:

$$
12 \mathrm{y} \square 14 \mathrm{y} \square 16 \mathrm{y} \square 18 \mathrm{y} \square 21 \mathrm{y} \square
$$

Number of Specialists: Full Time.

How many only Gastro: Full Time

Part time:

How many only Hepatology: Full Time:....... Part time:........

How many only Nutrition/Metabolic Diseases: Full Time:

Part time:

How many only Endoscopy: Full Time:....... Part time:..........

How many others subspeciality Full Time:. Part time:.

Special separate Clinic for:

IBD $\mathrm{Y} \square \mathrm{N} \square$

Motility $\mathrm{Y} \square \mathrm{N} \square$

Nutrition/Metabolic $\mathrm{Y} \square \mathrm{N} \square$

Cystic Fibrosis/Pancreas $\mathrm{Y} \square \mathrm{N} \square$

Hepatology/Liver transplantation Y $\square$ Hepatology Yes; Liver transplantation No $\mathrm{N}$

Others (Name. ..)

\section{ACTIVITY}

Number of out patients attended per year $\left(1^{\text {st }}\right.$ visit $\&$ follow up visits)

$$
<500 \square \text { 501-1500 } \square \text { 1501-3000 } \square \text { 3001-5000 } \square>5000 \square
$$

Number of in patients consultations offered per year $<500 \square 501-1500 \square$ 1501-3000 $\square>3000 \square$

PGHN in patients have: specific separate beds $\square$ General pediatrics beds

\section{EMERGENCIES}

The GHN Unit covers pedGI Emergency on-call: $\mathrm{Y} \square \mathrm{N} \square$

$$
<7 \text { days/month 8-14d/m 15-21 d/m daily }
$$

Is there a formal on-call roster? $\mathrm{Y} \square \mathrm{N} \square$

The trainees participate in the Emergency calls $\mathrm{Y} \square \mathrm{N} \square$ Are you on-call voluntarily $\mathrm{Y} \square \mathrm{N} \square$ Everybody must participate to the on-call

\section{PROCEDURES \& TECHNIQUES}

\section{ENDOSCOPY}

Endoscopy Unit

Free Access: $\mathrm{Y} \square \mathrm{N} \square$ 
Separate Suite attached to the GI training center: $\mathrm{Y} \square \mathrm{N} \square$ Attached to the Adults Endoscopy Unit: $\mathrm{Y} \square \mathrm{N} \square$

Specialised Endoscopy Nurses: Full Time:... Part time:. Are they AHP-ESPGHAN members $\mathrm{Y} \square \mathrm{N} \square$

Procedures: Diagnostic endoscopy $\mathrm{Y} \square \mathrm{N} \square$

Therapeutic endoscopy: Polypectomy Y $\square \mathrm{N} \square$ Removal of foreign bodies $\mathrm{Y} \square \mathrm{N} \square$

Gastrostomy placement $\mathrm{Y} \square \mathrm{N} \square$

Balloon dilatation $\mathrm{Y} \square \mathrm{N} \square$

Banding, Clips, sclerotherapy $\mathrm{Y} \square \mathrm{N} \square$

ERCP Y $\square \mathrm{N} \square$ (done by the adult GI)

Who performs the therapeutic endoscopy?

Pediatric Gastroenterologist

Pediatric Surgeon

Adult Gastro/Endoscopist

Other

Number of procedures per year

Diagnostic endoscopy Upper GIT: total/year:...

Diagnostic endoscopy Lower GIT: total/year:...

Therapeutic endoscopy: total/year: 30

Anaesthetists involved $\mathrm{Y} \square \mathrm{N} \square$

Video capsule performed: $\mathrm{Y} \square \mathrm{N} \square$ total number/year:.......

\section{OTHER TECHNIQUES}

Motility Techniques:

$\mathrm{pH} /$ monitoring $\mathrm{Y} \square \mathrm{N} \square$ total number/year:...

pH/Impedance: $\mathrm{Y} \square \mathrm{N} \square$ total number/year:...

Standard Manometry: $\mathrm{Y} \square \mathrm{N} \square$ total number/year:.

High Resolution Manometry: $\mathrm{Y} \square \mathrm{N} \square$ total number/year:...

Who performs the Motility Techniques?

Pediatric Gastroenterologist $\square$

Pediatric Surgeon $\square$

Adult Gastro

Other

Specialised Endoscopy Nurses: Full Time:... Part time:.

Are they AHP-ESPGHAN members $\mathrm{Y} \square \mathrm{N} \square$
Liver Biopsy

$\mathrm{Y} \square \mathrm{N} \square$ total number/year:...

Who is involved:

Pediatric Hepatologist $\square$

Pediatric Surgeons

Interventional radiologist $\square$

Other

Imaging Techniques

Fibroscan $\mathrm{Y} \square \mathrm{N} \square$

Other (specify).

Dietitians or doctors trained in nutrition attached to the GHN Unit:

$\mathrm{Y} \square \mathrm{N} \square$ Full Time: Part time:.

Are they AHP-ESPGHAN members $\mathrm{Y} \square$ one $\mathrm{N} \square$ one

Other Specialists attached to the GHN Unit:

Dietitians

Pharmacists

Specialized Nurses

Administrative staff

\section{Home Parenteral Nutrition Program}

$\mathrm{Y} \square \mathrm{N} \square<5 /$ year 5-10/year $>10 /$ year

Home Enteral (tube feeding) Nutrition Program

$\mathrm{Y} \square \mathrm{N} \square<5 /$ year 5-10/year $>10 /$ year

\section{Research Activities}

Has your Unit a recognised Research Activity Program $\mathrm{Y} \square \mathrm{N} \square$ attached to the Unit

attached to other Research groups $\square$

Does your unit have research laboratories (wet labs) Yes
Additional Comments or clarification: 
Supplementary Appendix 2 List of participating training centers in pediatric gastroenterology, hepatology and nutrition

\begin{tabular}{|c|c|c|c|}
\hline Country & City & Center & Head of the GI Unit \\
\hline \multirow[t]{3}{*}{ Austria } & Graz & Medical University of Graz & Almuthe Christine Hauer \\
\hline & Innsbruck & Medical University of Innsbruck & Thomas Müller \\
\hline & Vienna & Medical University of Vienna & Wolf-Dietrich Huber \\
\hline \multirow[t]{5}{*}{ Belgium } & Liège & MontLégia CHC Clinic & Colinet Stephanie \\
\hline & Leuven & Leuven-Gasthuisberg University Hospital & Ilse Hoffman \\
\hline & Brussels & Saint-Luc University Hospital & Etienne Sokal \\
\hline & Ghent & Ghent university hospital & Myriam Van Winckel \\
\hline & Brussels & Reine Fabiola University Hospital & Patrick Bontems \\
\hline \multirow[t]{3}{*}{ Bulgaria } & Sofia & $\begin{array}{l}\text { Sofia Specialized hospital for active treatment of child diseases Ivan } \\
\text { Mitev }\end{array}$ & Elena Lazarova \\
\hline & & Acibadem city clinick Tokuda Hospital & Kalin Lisichki \\
\hline & Varna & St Marina University Hospital for active treatment & Miglena Georgieva \\
\hline \multirow[t]{4}{*}{ Croatia } & Zagreb & Children's Hospital Zagreb & Sanja Kolaček \\
\hline & & University Hospital Center Zagreb & Jurica Vuković \\
\hline & & 'Sestre Milosrdnice’ University Hospital & Orjena Žaja \\
\hline & Rijeka & Rijeka University Hospital & Goran Palčevski \\
\hline \multirow[t]{3}{*}{$\begin{array}{l}\text { Czech } \\
\text { Republic }\end{array}$} & Prague & $\begin{array}{l}\text { Pediatric Gastroenterology Unit, Department of Pediatrics, University } \\
\text { Hospital Motol and Charles University }\end{array}$ & Jiri Bronsky \\
\hline & & $\begin{array}{l}\text { Pediatric Gastroenterology Unit, Department of Pediatrics, General } \\
\text { University Hospital and Charles University }\end{array}$ & Pavel Fruhauf, Peter Szitanyi \\
\hline & Olomouc & $\begin{array}{l}\text { Pediatric Gastroenterology Unit, Department of Pediatrics, University } \\
\text { Hospital Olomouc and Palacký University }\end{array}$ & Eva Karaskova \\
\hline \multirow[t]{11}{*}{ France } & $\begin{array}{l}\text { Le Kremlin- } \\
\text { Bicêtre }\end{array}$ & $\begin{array}{l}\text { Pediatric liver disease and pediatric liver transplantation, Paris-Sud } \\
\text { University, Medical School }\end{array}$ & Gonzales Emmanuel \\
\hline & Le Havre & Department of pediatrics, Jacques Monod Hospital & Valérie Bertrand \\
\hline & Lille & $\begin{array}{l}\text { Department of pediatric gastroenterology, hepatology and nutrition, } \\
\text { Lille University Hospital }\end{array}$ & Frederic Gottrand \\
\hline & Lyon & $\begin{array}{l}\text { Department of pediatric gastroenterology, hepatology and nutrition, } \\
\text { Lyon University Hospital }\end{array}$ & Sophie Heissat \\
\hline & Nancy & $\begin{array}{l}\text { Department of pediatric gastroenterology, hepatology and nutrition, } \\
\text { Nancy University Hospital }\end{array}$ & Emeline Guiot \\
\hline & Paris & $\begin{array}{l}\text { Department of pediatric gastroenterology, hepatology and nutrition, } \\
\text { Necker Hospital }\end{array}$ & Florence Lacaille \\
\hline & & $\begin{array}{l}\text { Department of pediatric gastroenterology and nutrition, Robert Debra } \\
\text { Hospital }\end{array}$ & Jean-Pierre Hugot \\
\hline & Rouen & Department of pediatrics, Rouen University Hospital & Olivier Mouterde \\
\hline & Strasbourg & $\begin{array}{l}\text { Department of pediatric gastroenterology, Strasbourg University } \\
\text { Hospital }\end{array}$ & Julie Rebeuh \\
\hline & Toulouse & $\begin{array}{l}\text { Department of pediatric gastroenterology, hepatology and nutrition, } \\
\text { Toulouse Universtary Hospital }\end{array}$ & Emmanuel Mas ${ }^{*}$ \\
\hline & Tours & Department of pediatrics, Tours University Hospital & Stephanie Willot \\
\hline \multirow[t]{3}{*}{ Germany } & Bremen & $\begin{array}{l}\text { Gesundheit Nord, Klinikum Links der Weser, Children's hospital, } \\
\text { Bremen }\end{array}$ & Martin Classen \\
\hline & Cologne & $\begin{array}{l}\text { Department of Pediatrics, University Children's Hospital, Cologne, } \\
\text { Germany }\end{array}$ & Ilse Broekaert \\
\hline & Darmstadt & Darmstädter Children’s Hospital Prinzessin Margaret, Darmstadt & Andreas Krahl \\
\hline
\end{tabular}


Supplementary Appendix 2 (Continued)

\begin{tabular}{|c|c|c|c|}
\hline Country & City & Center & Head of the GI Unit \\
\hline & Eisenach & St. Georg Hospital, Children’s Hospital, Eisenach & Benno Kretzschmar \\
\hline & Erlangen & $\begin{array}{l}\text { University Medical Center Erlangen, Department of Pediatrics and } \\
\text { Adolescent Medicine, Erlangen }\end{array}$ & André Hörning \\
\hline & Stuttgart & Klinikum Stuttgart, Olgahospital, Stuttgart & Söhnke Dammann \\
\hline & Tübingen & University Children’s Hospital Tübingen, Eberhard Karls University Tübingen & Ekkehard Sturm \\
\hline & Ulm & $\begin{array}{l}\text { University Medical Center Ulm, Department of Pediatrics and } \\
\text { Adolescent Medicine, Ulm }\end{array}$ & Carsten Posovszky \\
\hline \multirow[t]{4}{*}{ Greece } & \multirow[t]{2}{*}{ Athens } & $\begin{array}{l}\text { First Department of Pediatrics, University of Athens, Agia Sofia } \\
\text { Children's Hospital, Athens }\end{array}$ & Alexandra Papadopoulou \\
\hline & & $\begin{array}{l}\text { Third Department of Pediatrics, University of Athens, ATTIKON } \\
\text { University Hospital }\end{array}$ & Smaragdi Fessatou \\
\hline & \multirow[t]{2}{*}{ Thessaloniki } & Forth Department of Pediatrics, Aristotle University of Thessaloniki & Maria Fotoulaki \\
\hline & & $\begin{array}{l}\text { Third Department of Pediatrics, Aristotle University of Thessaloniki, } \\
\text { Hippokration Hospital }\end{array}$ & Ioannis Xinias \\
\hline \multirow[t]{4}{*}{ Hungary } & Budapest & First Department of Pediatrics, Semmelweis University & Áron Cseh \\
\hline & Debrecen & University of Debrecen, Clinical Center, Dep. of Pediatrics & Gábor Veres \\
\hline & Pécs & Department of Pediatrics, University Medical School of Pécs & Andras Tarnok \\
\hline & Szeged & Department of Pediatrics, University of Szeged & Daniel Szucs \\
\hline \multirow[t]{5}{*}{ Israel } & Haifa & $\begin{array}{l}\text { Pediatric Gastroenterology Unit at Ruth Rappaport Children's Hospital, } \\
\text { Rambam Medical center }\end{array}$ & Ron Shaoul \\
\hline & \multirow[t]{2}{*}{ Jerusalem } & Shaare Zedek Medical Center (Hebrew University) & Dan Turner \\
\hline & & $\begin{array}{l}\text { Pediatrics Department, Hadassah Mount Scopus - Hebrew University } \\
\text { medical center }\end{array}$ & Michael Wilschanski \\
\hline & Ramat Gan & Sheba Medical Center (Sackler Faculty of Medicine, Tel Aviv University) & Batia Weiss \\
\hline & Petach Tiqva & $\begin{array}{l}\text { Institute of Gastroenterology, Nutrition and Liver Diseases, Schneider } \\
\text { Children's Medical Center of Israel (Tel Aviv University) }\end{array}$ & Raanan Shamir \\
\hline \multirow[t]{8}{*}{ Italy } & Ancona & Marche Polytechnic University, Ancona University Hospital & Carlo Catassi \\
\hline & Bergamo & Papa Giovanni XXIII Hospital (affiliated to Milan and Pavia University) & $\begin{array}{l}\text { Lorenzo D’Antiga/Emanuele } \\
\text { Nicastro }\end{array}$ \\
\hline & Florence & Meyer University Hospital & Paolo Lionetti \\
\hline & Messina & Messina University Hospital & Claudio Romano \\
\hline & Naples & $\begin{array}{l}\text { Intradepartmental Program of Pediatric GI Endoscopy and Motility, } \\
\text { Department of Translational Medical Science, Section of Pediatrics }\end{array}$ & Annamaria Staiano \\
\hline & \multirow[t]{3}{*}{ Rome } & Sapienza University Hospital & Salvatore Cucchiara \\
\hline & & $\begin{array}{l}\text { Bambino Gesù Children's Hospital (affiliated to University of Rome La } \\
\text { Sapienza · Universita Cattolica del Sacro Cuore, Rome · University of } \\
\text { Rome Tor Vergata) }\end{array}$ & Luigi Dall'Oglio \\
\hline & & $\begin{array}{l}\text { Bambino Gesù Children's Hospital affiliated to University of Rome La } \\
\text { Sapienza } \text { Universita Cattolica del Sacro Cuore, Rome } \text { University of } \\
\text { Rome Tor Vergata) }\end{array}$ & Giuseppe Maggiore \\
\hline \multirow[t]{2}{*}{ Lithuania } & Kaunas & Hospital of Lithuanian University of Health Sciences Kauno klinikos & Ruta Kucinskiene \\
\hline & Vilnius & Center for Pediatrics of Vilnius University Hospital Santaros Klinikos & Vaidotas Urbonas \\
\hline \multirow[t]{2}{*}{ Portugal } & Lisbon & Santa Maria University Hospital Pediatric & Ana Isabel Gouveia Costa \\
\hline & Porto & São João University Hospital & Jorge Amil Dias (until 2021) \\
\hline \multirow[t]{2}{*}{ Slovenia } & Ljubljana & Ljubljana University Medical Center & Rok Orel \\
\hline & Maribor & Maribor University Medical Center & Jernej Dolinsek \\
\hline
\end{tabular}


Supplementary Appendix 2 (Continued)

\begin{tabular}{|c|c|c|c|}
\hline Country & City & Center & Head of the GI Unit \\
\hline \multirow[t]{11}{*}{ Spain } & Barakaldo & País Vasco University Hospital & $\begin{array}{l}\text { Iñaki Xarles Irastorza } \\
\text { Terradillos }\end{array}$ \\
\hline & \multirow[t]{2}{*}{ Barcelona } & Vall d'Hebron University Hospital & Jesus Quintero \\
\hline & & San Juan de Dios University Hospital & Javier Martín de Carpi \\
\hline & Córdoba & Reina Sofía University Hospital & $\begin{array}{l}\text { Rafael Gonzalez de Caldas } \\
\text { Marchal }\end{array}$ \\
\hline & Valencia & La Fe University Hospital & Carmen Ribes-Koninckx \\
\hline & Las Palmas & Materno-Infantil de Canarias University Hospital & Luis Peña-Quintana \\
\hline & \multirow[t]{2}{*}{ Madrid } & Niño Jesús University Hospital & Rosa Ana Muñoz Codoceo \\
\hline & & La Paz University Hospital & Manuel Molina \\
\hline & Málaga & Materno Infantil University Hospital & Víctor M. Navas López \\
\hline & Murcia & Virgen de la Arrixaca University Hospital & David Gil Ortega \\
\hline & Seville & Virgen del Rocio University Hospital & $\begin{array}{l}\text { Alejandro Rodriguez } \\
\text { Martinez }\end{array}$ \\
\hline \multirow[t]{5}{*}{ Switzerland } & Geneva & Pediatric Liver Center, University Hospitals Geneva & Valérie McLin \\
\hline & Lausanne & Lausanne University Hospital & Andreas Nydegger \\
\hline & Basel & University Children’s Hospital Basel & Raoul I. Furlano \\
\hline & Lucerne & Children's Hospital of Lucerne & Johannes Spalinger \\
\hline & St. Gallen & Children's Hospital of Eastern Switzerland in St. Gallen & George Marx / Pascal Müller \\
\hline \multirow{4}{*}{$\begin{array}{l}\text { The } \\
\text { Netherlands }\end{array}$} & Amsterdam & Emma Childrens Hospital / Academic Medical Center & Marc Benninga \\
\hline & Groningen & Groningen University Medical Center & Rene Scheenstra \\
\hline & Rotterdam & Erasmus University MC, Sophia Children’s Hospital & Hankje Escher \\
\hline & Utrecht & Wilhelmina Children's Hospital / Utrecht University Medical Center & Roderick Houwen \\
\hline \multirow[t]{3}{*}{ Turkey } & Ankara & Ankara University School of Medicine & Aydan Kansu \\
\hline & Izmir & Dokuz Eylul University School of Medicine & Yeşim Öztürk \\
\hline & Malatya & Inönü University Faculty of Medicine & Mukadder Ayșe Selimoğlu \\
\hline \multirow{13}{*}{$\begin{array}{l}\text { United } \\
\text { Kingdom }\end{array}$} & Birmingham & Birmingham Children’s Hospital (University of Birmingham) & Sue Protheroe \\
\hline & Bristol & Bristol Children’s Hospital & Dharam Basude \\
\hline & Cambridge & Cambridge University Hospital NHS Foundation Trust & Camilla Salvestrini \\
\hline & Leeds & Leeds Teaching Hospitals NHS Trust & Suzanne Davison \\
\hline & Liverpool & $\begin{array}{l}\text { Alder Hey Children's NHS Foundation Trust (Liverpool University NHS } \\
\text { Foundation Trust ) }\end{array}$ & Marcus KH Auth \\
\hline & \multirow[t]{3}{*}{ London } & Royal London Children's Hospital, Barts Health NHS Trust & Nicholas Croft \\
\hline & & $\begin{array}{l}\text { Great Ormond Street Hospital for Children NHS Foundation Trust, } \\
\text { London, UK }\end{array}$ & Nikhil Thapar (until 2019) \\
\hline & & King's College Hospital (London University NHS Foundation Trust) & Jonathan Hind \\
\hline & Manchester & $\begin{array}{l}\text { Royal Manchester Children's Hospital (Manchester University NHS } \\
\text { Foundation Trust) }\end{array}$ & Andrew Fagbemi \\
\hline & Nottingham & Nottingham University Hospitals NHS Trust & David Devadason \\
\hline & Oxford & Oxford University NHS foundation trust & Lucy Howarth \\
\hline & Sheffield & Sheffield Children's Hospital (affiliated to Sheffield Medical School) & Mike Thomson \\
\hline & Scotland & $\begin{array}{l}\text { North of Scotland Pediatric Gastroenterology, Hepatology and } \\
\text { Nutrition Network (NOSPGHANN) NHS Grampian, NHS Tayside, } \\
\text { NHS Highland, (NHS Orkney, NHS Shetland) }\end{array}$ & Dagmar Kastner-Cole \\
\hline
\end{tabular}

